\title{
EVALUASI PROGRAM GERDU KEMPLING SEBAGAI UPAYA PENANGGULANGAN KEMISKINAN DI KOTA SEMARANG (STUDI KASUS: KELURAHAN PALEBON KECAMATAN PEDURUNGAN)
}

\author{
Agustina Rahmawati \\ Prodi Ilmu Pemerintahan Fakultas Ekonomi dan Sosial \\ Universitas Amikom Yogyakarta \\ agustinarahma@amikom.ac.id
}

\begin{abstract}
Program Gerakan Terpadu di Bidang Kesehatan, Ekonomi, Pendidikan, Infrastruktur, dan Lingkungan or abbreviated Gerdu Kempling Semarang City Government was launched based on Local Regulation No. 4 of 2008 on Poverty Reduction and Semarang City Mayor Instruction 054/2/2011 on Accelerating Poverty Reduction Semarang City. This program targets poverty to fall by $2 \%$ every year. To achieve these objectives, Semarang City government cooperates with private parties, state-owned enterprises, universities and NGOs. One of the kelurahans who have implemented Gerdu Kempling program is the Palebon village. The subdistrict get CSR from PDAM Tirta Moedal, PT Telkom and Rotary Club for Rp 200 million which is used to carry out empowerment activities. However, there are some issues that affect the outcome of the Gerdu Kempling program in the Palebon subdistrict. Based on this study, this study evaluates the performance of Gerdu Kempling program in Palebon subdistrict by observing the phenomenon of input, process, output, and outcome. The approach used is mix methods. The data already collected will be presented and reduced then drawn conclusions. The results of this research are that the program input is correct, but the main problem is in the process of improper policy transformation which involves short time of empowerment that is only 1 year, the types of activities that are not in accordance with the needs of the community and not sustainable, and monitoring evaluation only administrative and no measure of success in the program. These problems affect the results of community appraisal of outputs and outcomes where most people state that they are not yet selfsufficient through the Gerdu Kempling program. However, the community also assessed the greatest impact felt is the field of environment and infrastructure.
\end{abstract}

Keywords: Poverty, Gerdu Kempling, Subdistrict

\section{A. PENDAhuluan:}

\section{Kemiskinan di Kota Semarang}

Kemiskinan merupakan masalah yang multikompleks dan ditemukan pada setiap negara termasuk di Indonesia. Data yang dilansir oleh Badan Pusat Statistik menunjukkan bahwa jumlah penduduk miskin di daerah perkotaan naik sebanyak 0,15 juta orang yakni dari 10,34 juta orang pada Maret 2016 menjadi 10,49 juta orang pada September 2016. Tingkat kemiskinan yang masih tinggi di Indonesia membuat pemerintah harus berupaya sangat keras untuk mengentaskan kemiskinan. Banyak programprogram pemerintah baik yang dibuat oleh pemerintah pusat maupun pemerintah daerah untuk mengurangi angka kemiskinan termasuk di Kota Semarang.

Angka penduduk miskin Kota Semarang yang ditetapkan berdasarkan Surat Keputusan Walikota Semarang tahun 2015 sejumlah 379.636 jiwa atau 117.933 Kepala Keluarga (KK).Jika dibandingkan dengan kota lainnya di Jawa Tengah, jumlah penduduk miskin Kota Semarang merupakan yang tertinggi. Kondisi tersebut tidak sebanding dengan tingkat kemiskinan yang angkanya merupakan terendah di Provinsi Jawa Tengah. 
Jumlah penduduk miskin tertinggi berada pada Kecamatan Semarang Utara dengan jumlah 46.100 jiwa dan diikuti Kecamatan Semarang Barat dengan jumlah 40.043 jiwa. Menurut penelitian yang dilakukan oleh Tri Wahyu Rejekiningsih (2011:28-44) dalam Jurnal Ekonomi
Pembangunan menyatakan bahwa Kemiskinan di Kota Semarang disebabkan oleh tingkat Pendidikan Kepala Keluarga yang rendah sedangkan harus memenuhi kebutuhan keluarganya, dan tidak merata nya distribusi bantuan kepada warga miskin di Kota Semarang.

Tabel 1

Data Warga Miskin Perkecamatan di Kota Semarang tahun 2015

\begin{tabular}{|c|l|c|c|c|}
\hline & \multicolumn{1}{|c|}{$\begin{array}{c}\text { NAMA } \\
\text { KECAMATAN }\end{array}$} & $\begin{array}{c}\text { JUMLAH } \\
\text { KELURAHAN }\end{array}$ & $\begin{array}{c}\text { JUMLAH } \\
\text { KK }\end{array}$ & $\begin{array}{c}\text { JUMLAH } \\
\text { JIWA }\end{array}$ \\
\hline 1 & $\begin{array}{l}\text { Semarang } \\
\text { Tengah }\end{array}$ & 15 & $6.088 \mathrm{KK}$ & 18.390 jiwa \\
\hline 2 & Semarang Utara & 9 & $13.775 \mathrm{KK}$ & 46.100 jiwa \\
\hline 5 & Genuk & 13 & $8.167 \mathrm{KK}$ & 26.264 jiwa \\
\hline 6 & Pedurungan & 12 & $7.745 \mathrm{KK}$ & 25.832 jiwa \\
\hline 7 & $\begin{array}{l}\text { Semarang } \\
\text { Selatan }\end{array}$ & 10 & $6.943 \mathrm{KK}$ & 21.371 jiwa \\
\hline 8 & Candisari & 7 & $7.662 \mathrm{KK}$ & 24.635 jiwa \\
\hline 9 & Gajahmungkur & 8 & $5.054 \mathrm{KK}$ & 15.901 jiwa \\
\hline 10 & Tembalang & 12 & $11.194 \mathrm{KK}$ & 36.823 jiwa \\
\hline 11 & Banyumanik & 11 & $4.642 \mathrm{KK}$ & 14.643 jiwa \\
\hline 12 & Gunungpati & 16 & $6.171 \mathrm{KK}$ & 19.188 jiwa \\
\hline 13 & Semarang Barat & 16 & $12.287 \mathrm{KK}$ & 40.043 jiwa \\
\hline 14 & Mijen & 14 & $4.868 \mathrm{KK}$ & 15.067 jiwa \\
\hline 15 & Ngaliyan & 10 & $6.925 \mathrm{KK}$ & 21.951 jiwa \\
\hline 16 & Tugu & 7 & $3.272 \mathrm{KK}$ & 10.709 jiwa \\
\hline Total & $\mathbf{1 6 ~ K e c a m a t a n}$ & $\mathbf{1 7 7}$ Kelurahan & $\mathbf{1 1 7 . 9 3 3 \mathbf { K K }}$ & $\mathbf{3 7 9 . 6 3 6}$ jiwa \\
\hline
\end{tabular}

Sumber: Bappeda Kota Semarang, 2015

Pemerintah Kota Semarang pun telah membuat program untuk mengurangi angka kemiskinan di Kota Semarang tersebut. Salah satu program yang sudah dijalankan oleh Pemerintah Kota Semarang untuk mengentaskan kemiskinan adalah Program Gerakan Terpadu di Bidang Kesehatan, Ekonomi, Pendidikan, Infrastruktur, dan Lingkungan atau yang disingkat Gerdu Kempling. Program ini digulirkan Pemerintah Kota Semarang pada bulan Mei tahun 20112015 berdasarkan Peraturan Daerah Nomor 4 tahun 2008 tentang Penanggulangan Kemiskinan dan Instruksi Walikota Semarang nomor 054/2/2011 tentang Percepatan Penanggulangan Kemiskinan Kota Semarang melalui Program Gerdu Kempling Tahun 2011. Program ini dirancang sebagai tindakan untuk percepatan penanggulangan kemiskinan di Kota Semarang, pemerintah mentargetkan dengan dilaksanakannya program Gerdu Kempling maka kemiskinan dapat turun $2 \%$ setiap tahunnya. Untuk mencapai tujuan tersebut maka pemerintah Kota Semarang bekerjasama dengan pihak swasta dan BUMN sebagai pihak pemberi bantuan melalui program CSR, Perguruan Tinggi/ LSM/Tokoh Masyarakat sebagai pihak yang melakukan pembinaan terhadap masyarakat miskin, dan pemerintah sebagai pihak yang memegang fungsi pengendalian dan pengawasan. Strategi dari program ini adalah bersinergi dan membangun kemitraan dengan pihak swasta dan Perguruan Tinggi untuk memberdayakan masyarakat seperti pada gambar dibawah ini: 


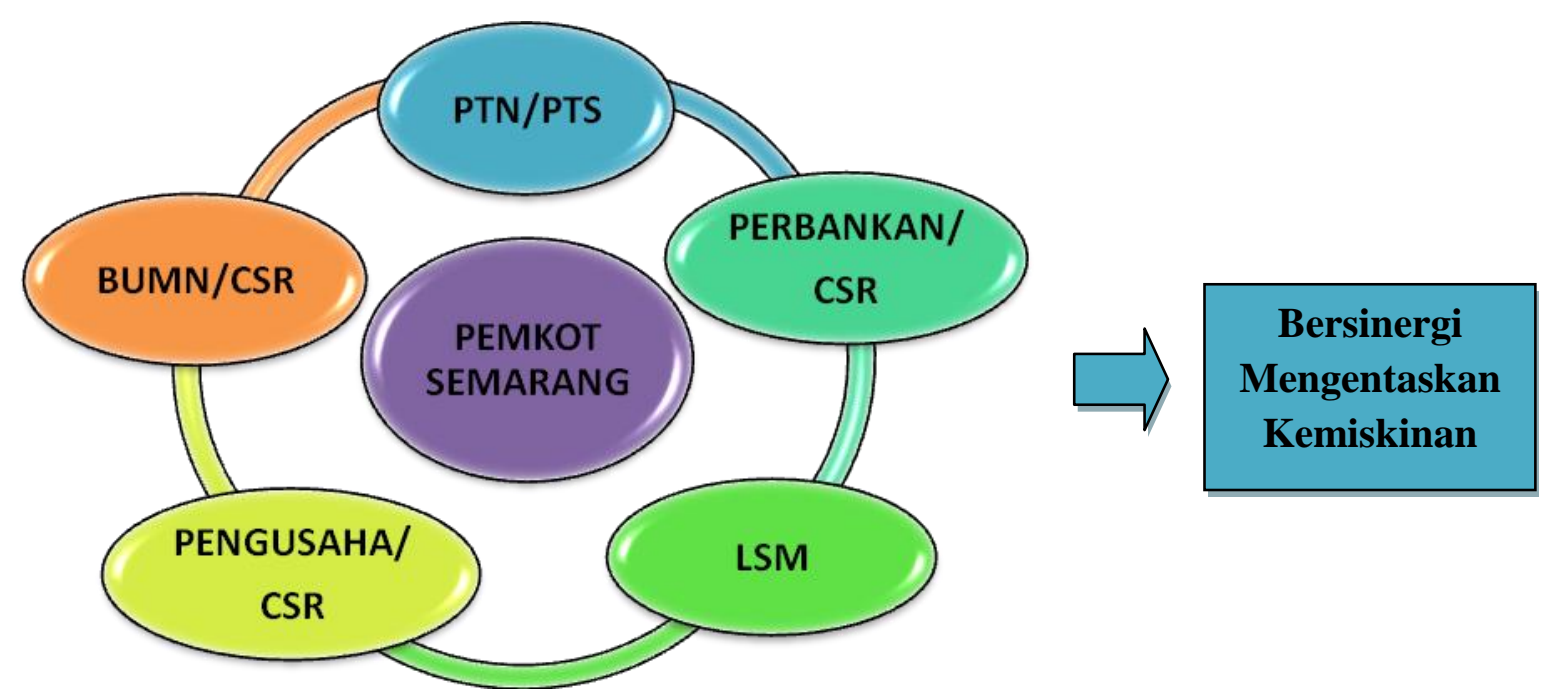

Gambar 1

Sinergi dan Kemitraan Program Gerdu Kempling.

Sumber: Bappeda Kota Semarang, 2011.

Program Gerdu Kempling ini menargetkan pelaksanaannya yaitu 32 kelurahan pada tahun 2011, 48 kelurahan pada tahun 2012, 48 kelurahan pada tahun
2013, 32 kelurahan pada tahun 2014 dan 17 kelurahan pada tahun 2015, seperti pada tabel dibawah ini:

Tabel 2

Target Capaian Kelurahan Program Gerdu Kempling

\begin{tabular}{|c|c|}
\hline Tahun & Target pelaksanaan \\
\hline 2011 & 32 kelurahan \\
\hline 2012 & 48 kelurahan \\
\hline 2013 & 48 kelurahan \\
\hline 2014 & 32 kelurahan \\
\hline 2015 & 17 kelurahan \\
\hline
\end{tabular}

Sumber: Bappeda Kota Semarang, 2017

Menurut Bappeda, pada tahun 2011 dan tahun 2012 telah mencapai angka tersebut diatas, dengan capaian pada tahun 2012 dana CSR yang terkumpul adalah Rp.19.266.182.500. Dengan dana tersebut dapat mencakup 7934 KK untuk diberdayakan. Dan target yang dicapai adalah $6,17 \%$ penurunan masyarakat miskin. Angka tersebut jauh diatas target Pemerintah Kota Semarang yang mentargetkan menurunkan angka kemiskinan $2 \%$ per tahun. Namun sayangnya, Bappeda tidak dapat menjelaskan ukuran dari terlepasnya masyarakat dari kemiskinan tersebut.Tolak ukurnya adalah apabila mereka berhasil 'mandiri'.

Pelaksanaan Program Gerdu Kempling tidak lepas dari berbagai permasalahan yang muncul mulai dari input program sampai dengan outcome atau dampak dari program tersebut, berikut adalah permasalahan-permasalahan program Gerdu Kempling yang dirinci dari input kebijakan sampai dengan outcome kebijakan: 
1. Input: permasalahan utama pada input kebijakan adalah sumber daya waktu. Proses: terdapat beberapa permasalahan pada tahap proses adalah sebagai berikut:

a. Beberapa wilayah memiliki partisipasi dari masyarakat yang rendah dalam program ini.

b. Pertemuan yang tidak intensif pada pemberdayaan program Gerdu Kempling karena kurun waktu yang terbatas. Keterbatasan waktu ini juga membuat kegiatan pemberdayaan program Gerdu kempling menjadi tidak berkelanjutan.

c. Program ini dirancang untuk mengentaskan kemiskinan di Kota Semarang dengan target $2 \%$ setiap tahunnya. Namun, pemerintah kota sebagai pihak pembuat kebijakan tidak menentukan ukuran-ukuran keberhasilan pemberdayaan dari program Gerdu Kempling atau ukuran bahwa masyarakat miskin sebagai target group telah lepas dari kemiskinan. Masyarakat miskin yang telah terkena program Gerdu kempling dianggap telah terentaskan dari kemiskinan dan dihapus datanya sebagai masyarakat miskin. Padahal belum tentu masyarakat yang mengikuti program Gerdu Kempling tersebut terentaskan dari kemiskinan. Berdasarkan data yang didapatkan dari Implemantasi Program Gerdu Kempling, menyatakan bahwa pada tahun 2014 program Gerdu Kempling berhasil menurunkan angka kemiskinan sebesar $6,17 \%$ tanpa menerangkan ukuran-ukurannya.

2. Output (hasil): Keberhasilan masih bias, kemandirian masyarakat daerah tertentu belum terukur.

3. Outcome (dampak): setelah semua kegiatan selesai dilaksanakan tidak ada feed back atau umpan balik untuk memperbaiki atau melanjutkan kegiatan pemberdayaan. Pihak Bappeda Kota Semarang pun menyatakan bahwa, evaluasi memang dilakukan namun tidak untuk memperbaiki atau melanjutkan kegiatan pemberdayaan pada tempat yang sama tetapi untuk bahan introspeksi agar pelaksanaaan pemberdayaan masyarakat di Kelurahan Palebon, Kecamatan Pedurungan selanjutnya lebih baik.

Selain itu, Kepala Bappeda menyatakan permasalahan lainnya yang muncul dalam pelaksanaan program Gerdu Kempling adalah masyarakat miskin yang sulit merubah mindset dan meninggalkan budaya miskin tersebut. Hal ini jelas akan terjadi karena keterbatasan waktu kegiatan pemberdayaan Gerdu Kempling di beberapa wilayah kota Semarang tidak berjalan secara kontinyu dan berkelanjutan sampai dirasakan masyarakat menjadi mandiri seperti yang telah dijelaskan di atas.

Sedangkan untuk mengubah mindset dan budaya miskin masyarakat tersebut tidak bisa dilakukan dalam waktu yang singkat karena harus melalui proses yang dilakukan secara kontinyu dan berkelanjutan sampai dirasakan bahwa masyarakat mampu dan siap menjadi mandiri sehingga mindset dan budaya miskin tersebut dapat ditinggalkan. Menurut Soetomo (2006:152), sesuai dengan prinsip community development, peranan petugas lapangan tidak terbatas pada bagaimana menyampaikan teknologi, skill, dan pengetahuan baru serta menjembatani sumber daya dari luar komunitas agar dapat memberi manfaat bagi perkembangan komunitas, tetapi adalah bagaimana mendorong tetap lestarinya proses pembangunan dan pembaruan pada tingkat komunitas tersebut.

$$
\text { Menurut Sulistyani }
$$
pemerintah masih memandang kemiskinan sebagai fenomena. Kemiskinan secara eksplisit adalah sebagai fenomena, yakni hanya akan dilihat bagaimana upaya masyarakat dalam memenuhi kebutuhan, dan sampai sejauhmana upaya tersebut mampu meraih apa yang diinginkan. Aras pemikiran ini terlalu dangkal dan tidak menyentuh masalah yang lebih mengakar pada inti 
persoalan yang sesungguhnya. Pada prinsipnya kemiskinan bukan sekedar fenomena, akan tetapi lebih merupakan proses yang tereduksi akibat kerentanan yang melanda pada banyak faktor. Kemiskinan akan terentaskan jika program diarahkan untuk memberikan stimulant bagi upaya pemberdayaan masyarakat yang berkelanjutan, dengan demikian masyarakat akan melakukan proses menuju kemandirian sejati.

Penelitian mengenai evaluasi program kemiskinan telah banyak dilakukan. Penelitian-penelitian tersebut mengkaji berbagai macam program yang dijalankan oleh pemerintah sebagai usaha untuk mengentaskan kemiskinan.Warih Budiyono (2008) meneliti tentang Evaluasi Proses Pelaksanaan Program Pengembangan Kecamatan (PPK) di Kecamatan Karangmojo Kabupaten Gunung Kidul.Hasil penelitian menunjukkan bahwa PPK telah dilaksanakan sesuai dengan prinsip program tersebut dengan baik, namun belum dapat mengubah kehidupan masyarakat miskin didaerah tersebut.Sedangkan Tri Effiandi (2010) meneliti tentang Evaluasi Kebijakan Bantuan Langsung Tunai di Kabupaten Muara Enim (Studi Kasus di Kecamatan Lawang Kidul).Hasil kebijakan menunjukkan bahwa bantuan yang diberikan pemerintah pusat berupa uang tunai tersebut tidak digunakan sebagaimana mestinya sehingga tidak berdampak pada kesejahteraan masyarakat dan direkomendasikan agar kebijakan BLT dihentikan.

Penelitian-penelitian terdahulu tersebut memiliki keterbatasan-keterbatasan, yaitu: Pertama, penelitian-penelitian terdahulu tersebut tidak memperhatikan pada sisi keberlanjutan program atau paradigma pemberdayaan community development sebagai bentuk pembangunan yang berkelanjutan yang berdampak pada kemandirian masyarakat. Kedua, semua penelitian di atas meneliti program-program pengentasan kemiskinan yang dibuat oleh pemerintah pusat.Ketiga, penelitian-penelitian terdahulu merupakan penelitian pada program yang dalam pelaksanaannya hanya melibatkan satu pihak yaitu pemerintah.Keempat, penelitian-penelitian tersebut tidak mengukur kebijakan dari segi input, proses, output, dan outcome kebijakan. Oleh karena itu, dalam penelitian ini akan diteliti tentang evaluasi input, proses, output, dan outcome dari program inovasi yang dibuat oleh pemerintah daerah yang bersinergi dengan pihak swasta dan perguruan tinggi dalam mengentaskan kemiskinan yaitu Gerdu Kempling dan sekaligus sebagai bentuk program CSR dari pihak swasta dan perguruan tinggi yang terlibat.

Berdasarkan permasalahan yang telah dikemukakan di atas, maka penelitian ini diberi judul Evaluasi Program Gerdu Kempling Sebagai Upaya Penanggulangan Kemiskinan di Kota Semarang (Studi Kasus: Kelurahan Palebon, Kecamatan Pedurungan). Berdasarkan Latar Belakang di atas maka Perumusan Masalah dari penelitian ini adalah: Bagaimana ketepatan input, proses pelaksanaan, dan dampak dari program Gerdu Kempling di Kelurahan Palebon, Kecamatan Pedurungan, Kota Semarang?

Tujuan Penelitian ini adalah :

1. Untuk mengetahui ketepatan input program Gerdu Kempling di Kelurahan Palebon, Kecamatan Pedurungan Kota Semarang.

2. Untuk mengetahui proses pelaksanaan program Gerdu Kempling di Kelurahan Palebon, Kecamatan Pedurungan Kota Semarang.

3. Untuk mengetahui dampak program Gerdu Kempling terhadap kondisi kesehatan, ekonomi, pendidikan, infrastruktur, dan lingkungan masyarakat miskin di Kelurahan Palebon, Kecamatan Pedurungan Kota Semarang.

Evaluasi kebijakan merupakan tahapan akhir dalam siklus kebijakan publik.Menurut Nugroho (2003:185), istilah evaluasi dapat disamakan dengan penaksiran (appraisal), pemberian angka (rating), dan penilaian (assessment).Edward A. Suchman 
dalam Nugroho (2003:199), mengemukakan metode evaluasi kebijakan terdiri dari enam langkah sebagai berikut: 1).Mengidentifikasi tujuan program yang akan dievaluasi, 2).Analisis terhadap masalah, 3).deskripsi dan standarisasi kegiatan, 4).Pengukuran terhadap tingkatan perubahan yang terjadi.. 5).Menentukan apakah perubahan yang diamati merupakan akibat dari kegiatan tersebut atau karena penyebab yang lain, 6).beberapa indikator untuk menetukan keberadaan suatu dampak.

Pengukuran evaluasi bervariasi sesuai dengan tipe evaluasinya.Tipe evaluasi kecocokan, efektivitas dan efisiensi mungkin memerlukan investigasi yang mendalam sebelum sampai pada kesimpulan akhir.pengukuran evaluasi tersebut bervariasi, secara umum evaluasi kinerja kebijakan tersebut mengacu pada empat indikator pokok yaitu indikator input, process, outputs, dan outcomes (Bridgman dan Davis, 2000:130).

Menurut Ambar Teguh (2004:6), Substansi kemiskinan di Perkotaan dapat dipahami sebagai suatu kondisi deprivasi terhadap sumber-sumber pemenuh kebutuhan dan rendahnya aksessabilitas terhadap fasilitas pembangunan, baik pada sektor ekonomi, politik, sosial, dan budaya. Kemiskinan berdimensi ini muncul karena kota yang menawarkan banyak harapan telah banyak diminati oleh masyarakat pinggiran dan pedesaan yang ingin mereguk penghidupan lebih baik. Faktor lain yang memunculkan kemiskinan perkotaan adalah pembangunan fisik kota yang memerlukan areal yang maha luas. Pertumbuhan kota telah menyerap banyak sumber daya dan mampu mengubah orientasi. Gejala umum yang terjadi pada setiap pertumbuhan kota selalu dibarengi oleh perubahan mekanisme ekonomi yang semula agraris menjadi basis industri. Hal itu memiliki konsekuensi perubahan mata pencaharian bagi penduduknya.Setting ekonomi, sosial, budaya, agraris digantikan dengan perilaku ekonomi modern (industri), atau setidaknya bentuk transisi menuju budaya industri.

Christenson dan Robinson dalam Soetomo (2006:81), community development sebagai suatu proses dimana masyarakat yang tinggal pada lokasi tertentu mengembangkan prakarsa untuk melaksanakan suatu tindakan sosial (dengan atau tanpa intervensi) untuk mengubah situasi ekonomi, sosial, kultural, dan atau lingkungna mereka.Selain itu, konsep community development mengandung potensi kontradiksi.Hal ini disebabkan karena dalam konsep community terkandung tiga elemen penting yaitu lokalitas (local ecology), kehidupan sosial yang terorganisasi dan solidaritas sosial.

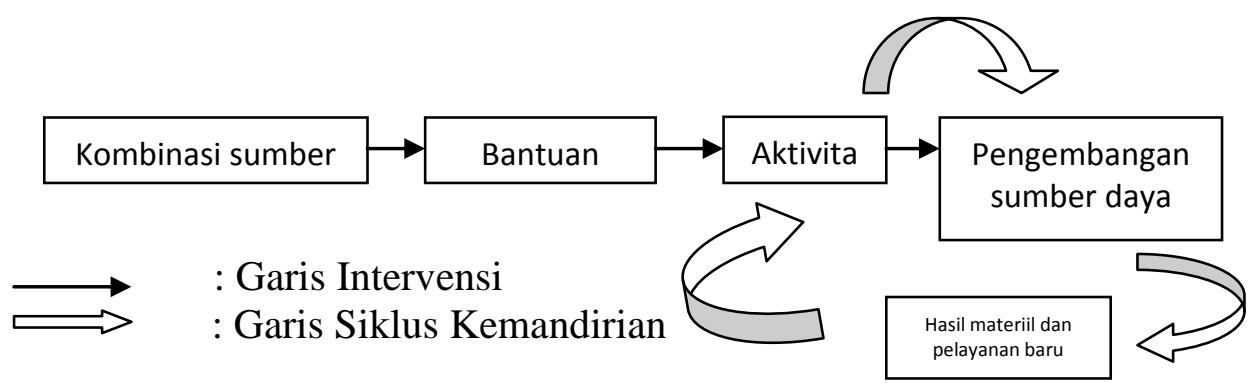

Gambar 2.1: Intervensi yang berdampak kemandirian

Sumber: Honadle dan Vant Sant dalam Soetomo (2006:423)

\begin{abstract}
Agar intervensi dari luar dapat mendorong tumbuhnya kompetensi masyarakat dan memunculkan prakarsa lokal, maka perlu memerhatikan pentahapan dalam pelaksanaanya. Biddle dalam Soetomo
\end{abstract}

(2006:143) merekomendasikan enam tahap yaitu : 1).Exploratory: tahap ini berisi kegiatan- kegiatan untuk memahami kondisi, situasi dan potensi masyarakatnya; 2).Organizational: tahap ini berisi kegiatan 
untuk menentukan media yang dapat digunakan sebagai sarana pertemuan dan diskusi antara petugas dengan masyarakat maupun antar sesama warga masyarakat; 3).Discussional : tahap ini berisi kegitan diskusi antar warga masyarakat tentang inventarisasi masalah serta kemungkinan pemecahannya, memilih alternative yang pantas memperoleh prioritas dalam penanganannya, membuat keputusan tetntang kegiatan bersama yang akan dilaksanakan dan membuat rencana pelaksanaannya; 4).Action : tahap ini berisi pelaksanaan kegiatan yang sudah diputuskan bersama, serta melaporkan dan mengevaluasi hasilnya; 5).New project: tahap ini mengulang kegiatan diskusi untuk menentukan masalah apa yang sebaiknya digarap pada prioritas berikutnya, kemudian membuat rencana dan melaksanakannya dengan memerhatikan pengalaman pelaksanaan sebelumnya; 6).Continuation: dalam tahap ini mekanisme pelaksanaan pembangunan berdasar prakarsa masyarakat dianggap sudah melembaga. Dengan demikian, petugas lapangan dapat meninggalkan masyarakat yang bersangkutan. Walaupun intervensi dari luar sudah dihentikan, kesinambungan proses pembangunan diharapkan tetap berjalan.

Menurut Budimanta (2003), CSR merupakan sebuah pendekatan yang dilakukan untuk mengintegrasikan kepedulian sosial dalam interaksi dengan berbagai stakeholders, yang berdasarkan pada prinsip sukarela maupun kemitraan.Menurut Badaruddin (2008), pendekatan CSR hendaknya dilakukan secara holistik, yang bersifat derma (charity) dan ditekankan pada keberlanjutan pengembangan masyarakat (community development).Selain itu terdapat pula model pemberdayaan masyarakat melalui program CSR menurut Badaruddin yang disebut Model Kerja Kolaborasi yang didasarkan pada asumsi bahwa tidak ada satupun pihak yang sanggup secara sendirian menjalankan fungsi yang sangat kompleks dalam upaya pemberdayaan masyarakat miskin. Model ini dianggap sangat relevan dengan tuntutan perusahaan untuk menjalankan Good Corporate Governance (GCG).

\section{B. METODE PENELITIAN}

Fokus pada penelitian ini adalah evaluasi kebijakan dari program Gerdu Kempling di Kota Semarang yang merupakan kerjasama Pemerintah Kota Semarang dengan CSR (Corporate Social Responsibility) di bidang kesehatan, ekonomi, pendidikan, infrastruktur dan lingkungan. Pada penelitian ini wilayah yang dijadikan objek penelitian adalah Kelurahan Palebon. Kecamatan Pedurungan, Kota Semarang, Jawa Tengah. Fenomena yang diamati dalam penelitian ini adalah kinerja dari kebijakan pemerintah dalam mengentaskan kemiskinan di Kota Semarang melalui Program Gerdu Kempling. Penilaian kinerja Program Gerdu Kempling di Kota Semarang menggunakan teori ukuran evaluasi dari Bridgman dan Davis yaitu input, proses, output, dan outcome.

Pada penelitian ini, data sumber primer berasal dari masyarakat Kelurahan Palebon, Kecamatan Pedurungan, Kota Semarang yang terlibat dalam program Gerdu Kempling, pihak aparatur kelurahan, pihak aparatur Bappeda Kota Semarang, dan pihak CSR. Sedangkan data sumber sekunder berasal dari dokumentasi-dokumentasi yang berkaitan dengan program Gerdu Kempling. Adapun pemilihan dilakukan dengan menggunakan tehnik "purposive". Teknik purposive adalah teknik penentuan informan dengan pertimbangan tertentu. Penelitian ini menggunakan mix methods dengan menggunakan data kuantitatif sekunder. Urutan tahap dan proses analisis data Miles Huberman adalah sebagai berikut (1) pengolahan data, yang terdiri dari kategorisasi dan reduksi data, (2) penyajian data, (3) interpretasi data, (4) penarikan kesimpulankesimpulan/verifikasi.Selain itu, penelitian ini juga menggunakan teknik analisis taksonomi.Teknik ini digunakan untuk menganalisis fenomena-fenomena atau domain-domain secara lebih mendalam 
sehingga data-data yang didapatkan tersebut dapat disimpulkan.

\section{HASIL DAN PEMBAHASAN}

Analisis Realisasi Input, Proses, Output dan Outcome Program Gerdu Kempling di Kelurahan Palebon

Penelitian ini menggunakan teori yang dikemukakan oleh Bridgman dan Davis, berdasarkan teori tersebut terdapat empat fenomena yang dikaji dalam pembahasan penelitian ini.Keempat fenomena tersebut adalah Pertama, input dengan mengamati a) sumber daya pendukung dan bahan-bahan dasar yang diperlukan untuk melaksanakan program Gerdu Kempling. b) sumber daya manusia, uang, atau infrastruktur pendukung lainnya. Kedua, proses dengan mengamati a) Pentransformasian kebijakan gerdu kempling ke dalam bentuk pelayanan langsung kepada masyarakat. b) efektivitas dan efisiensi dari metode pemberdayaan yang digunakan untuk melaksanakan program gerdu kempling. Ketiga, output dengan mengamati a) hasil atau produk yang dihasilkan dari pelaksanaan program Gerdu Kempling di kelurahan Palebon. b) jumlah warga miskin yang berhasil diberdayakan/dimandirikan melalui program Gerdu Kempling. Keempat, outcome dengan mengamati bentuk dampak yang diterima masyarakat miskin berdasarkan sasaran program Gerdu Kempling di kelurahan Palebon.
1. Input, yang diamati dari gejala:

Ketepatan sumber daya pendukung, bahan-bahan dasar yang diperlukan, sumber daya manusia, uang, dan infrastruktur pendukung lainnya:

Program Gerdu Kempling di kelurahan Palebon yang merupakan CSR dari PDAM Tirta Moedal, PT. Telkom dan Rotary Club yang memiliki total 8 kegiatan yang masing-masing dari kegiatan tersebut memiliki input yang berbeda-beda. Berdasarkan penelitian, input untuk tiap kegiatan dalam program Gerdu Kempling di kelurahan Palebon sudah tepat. Dana yang diberikan tidak mengalami kekurangan untuk membeli bahan-bahan dan alat-alat yang dibutuhkan sehingga dengan dana tersebut kegiatan pun berjalan dengan lancar, hal ini dikarenakan oleh pembelian bahan-bahan dan alat-alat yang dibutuhkan untuk melaksanakan kegiatan disesuaikan dengan dana yang diberikan oleh pihak PDAM Tirta Moedal.

Sumber daya manusia pada masingmasing kegiatan pun juga tidak mengalami kekurangan dan hambatan dikarenakan orangorang yang ditunjuk untuk melaksanakan kegiatan adalah orang-orang yang tepat dan ahli terhadap bidang tersebut. Berikut adalah daftar kompetensi SDM yang melakukan penyuluhan pada kegiatan pemberdayaan program Gerdu Kempling di Kelurahan Palebon.

Tabel 3

Daftar Kompetensi Sumber Daya Manusia

Program Gerdu Kempling di Kelurahan Palebon

\begin{tabular}{|c|c|c|c|}
\hline No. & Sumber Daya Manusia & Kompetensi & Kegiatan Pemberdayaan \\
\hline 1. & PT. Telkom & Bidang Pendidikan & $\begin{array}{l}\text { Pendirian Rumah Pintar, } \\
\text { Bantuan Komputer } \\
\text { Rumah Pintar dan } \\
\text { Langganan internet }\end{array}$ \\
\hline 2. & PDAM Tirta Moedal & Bidang Ekonomi & $\begin{array}{l}\text { Bantuan Bergulir Modal } \\
\text { Usaha Ekonomi } \\
\text { Produktif dengan } \\
\text { memberikan fasilitas } \\
\text { bantuan berupa alat-alat } \\
\text { pembuatan serabi, serta } \\
\text { teknik pemasaran } \\
\text { produk. }\end{array}$ \\
\hline
\end{tabular}




\begin{tabular}{|l|l|l|l|}
\hline 3. & $\begin{array}{l}\text { Universitas } \\
\text { Muhammadiyah } \\
\text { Semarang (UNIMUS) }\end{array}$ & Bidang Ekonomi & $\begin{array}{l}\text { Mindset Training dan } \\
\text { membantu } \\
\text { pendampingan teknik } \\
\text { pemasaran produk }\end{array}$ \\
\hline 4. & Rotary Club & $\begin{array}{l}\text { Bidang Sosial dan } \\
\text { Pendidikan }\end{array}$ & $\begin{array}{l}\text { Bantuan 2000 Buku } \\
\text { Bacaan Untuk Rumah } \\
\text { Pintar, 3 Unit APE } \\
\text { Outdoor dan Pelatihan } \\
\text { Tata Boga }\end{array}$ \\
\hline 5. & Dinas Kesehatan & Bidang Kesehatan & $\begin{array}{l}\text { Memberikan penyuluhan } \\
\text { kesehatan masyarakat. }\end{array}$ \\
\hline 6. & Pihak Kelurahan & $\begin{array}{l}\text { Bidang Tata Kelola } \\
\text { Organisasi dan } \\
\text { Kelembagaan }\end{array}$ & $\begin{array}{l}\text { Memberikan sosialisasi } \\
\text { tata kelola organisasi } \\
\text { kelompok usaha } \\
\text { masyarakat serta } \\
\text { sekaligus pendampingan } \\
\text { wargadalam seluruh } \\
\text { kegiatan pelatihan }\end{array}$ \\
\hline 7. & $\begin{array}{l}\text { Pihak Ibu-ibu Kader } \\
\text { PKK }\end{array}$ & Bidang Kerajinan & $\begin{array}{l}\text { Pelatihan pembuatan } \\
\text { kerajinan payet, bunga } \\
\text { dari kain perca dan } \\
\text { lukisan wayang kulit. }\end{array}$ \\
\hline 8. & $\begin{array}{l}\text { Dinas Tata Kota Kota } \\
\text { Semarang }\end{array}$ & Bidang Penghijauan & $\begin{array}{l}\text { Penanaman buah } \\
\text { mangga di Kelurahan } \\
\text { Palebon }\end{array}$ \\
\hline
\end{tabular}

Sumber: Bappeda Kota Semarang, 2015

2. Proses, yang diamati dari gejala:

a. Pentransformasian kebijakan Program Gerdu Kempling kedalam bentuk pelayanan langsung kepada masyarakat.

Program Gerdu Kempling dirancang oleh pemerintah kota Semarang untuk mengentaskan angka kemiskinan dengan cara bekerjasama dengan pihak swasta atau BUMN dan Perguruan- perguruan Tinggi yang ada di kota Semarang. Pihak swasta dan BUMN sebagai pihak pemberi bantuan melalui program CSR, Perguruan Tinggi sebagai pihak yang melakukan pembinaan terhadap masyarakat miskin, LSM sebagai pemantau independen dan pemerintah sebagai pihak yang memegang fungsi pengendalian dan pengawasan.

Setiap kelurahan akan mendapatkan perusahaan dan perguruan tinggi yang akan memberikan dana dan melakukan kegiatan program Gerdu Kempling di kelurahan tersebut sesuai yang telah diatur oleh pemerintah kota Semarang. Kelurahan Palebon sendiri mendapatkan PDAM Tirta Moedal, PT Telkom dan Rotary Club sebagai pemberi dana CSR dan UNIMUS sebagai pihak pembina dalam kegiatan pemberdayaan program Gerdu Kempling. Untuk melaksanakan semua kegiatan tersebut, pemerintah kota Semarang memberikan waktu 1 tahun, sesuai dengan waktu yang diberikan oleh pemerintah kota Semarang. Semua kegiatan berjalan dengan baik dan terselesaikan tepat pada waktunya.

Namun, apabila dilihat dari jenis-jenis kegiatannya, kegiatan pemberdayaan di kelurahan Palebon ini hanya sebagian kecil yang sesuai dengan potensi dan kebutuhan masyarakat Palebon akibatnya kegiatan tersebut tidak bersifat berkelanjutan dan tidak membawa perubahan dalam 
masyarakat.Beberapa kegiatan yang tidak sesuai dengan potensi dan kebutuhan masyarakat adalah Pelatihan Tata Boga yakni pembuatan serabi beserta bantuan alatalatnya.Selain itu, ada beberapa kegiatan yang juga hanya bersifat sekedar sosialisasi tanpa adanya kelanjutan, yaitu Mind Set Training dan Penyuluhan Kesehatan Masyarakat.

Pertama, Pelatihan Tata Boga yakni pembuatan serabi beserta bantuan pembelian alat-alatnya. Hal tersebut difasilitasi oleh pihak PDAM Tirta Moedal yang memberikan bantuan bergulir modal usaha untuk meningkatkan produktivitas masyarakat khususnya para ibu-ibu rumah tangga agar memiliki tambahan untuk memenuhi kebutuhan hidup melalui menjual serabi. PDAM Tirta Moedal juga memberikan bantuan berupa alat-alat pembuatan serabi.Namun, serabi ternyata kurang banyak diminati masyarakat serta laba yang diperoleh ibu-ibu hanya sedikit sehingga kegiatan ini tidak berkelanjutan. Bahkan alat-alat pembuatan serabi justru dijual kembali oleh ibu-ibu karena tak banyak digunakan.

Kedua, Pelatihan Pemasaran Produk Pembuatan Payet, bunga dari kain perca dan lukisan wayang kulit. Pelatihan ini hanya kurang mendalam dan hanya sekedar materi sosialisasi saja, pendampingan pemasaran produk dilakukan hanya 3 kali ketika diadakan pameran ekspo di Kelurahan Palebon saja. Sehingga hasil produk hanya dipasarkan seketika itu saja, tanpa adanya monev lagi dari pihak CSR, Dinas, maupun UNIMUS setelah kegiatan itu selesai.

Ketiga, Bantuan Penghijauan. Dinas Tata Kota memberikan bantuan penghijauan 20 batang pohon mangga untuk penghijauan. Hal ini tujuannya untuk ceremoni pembukaan Gerdu Kempling yang dihadiri Walikota Semarang pada saat itu dan Pihak CSR juga UNIMUS. Pohon-pohon mangga ini sebagian besar ditanam di SDN Palebon dan depan Kelurahan Palebon. Namun, sebenarnya di sekitar SDN Palebon dan Kelurahan Palebon sudah tertanam banyak pohon dan kondisinya tidak gersang seperti gambar dibawah
ini.Penghijauan bukanlah hal yang sangat dibutuhkan di kelurahan Palebon.

Berdasarkan hasil penelitian, monitoring dan evaluasi dilakukan oleh Bappeda kota Semarang sebanyak 3 kali yaitu caturwulan 1, caturwulan 2, dan caturwulan 3 . Namun monitoring dan evaluasi ini bukanlah bentuk monev lapangan. Monev program Gerdu Kempling hanya berupa penyerahan laporan pelaksanaan kegiatan setiap caturwulan kepada Bappeda.

Hal ini menunjukkan bahwa program Gerdu Kempling tidak memiliki indikator keberhasilan pelaksanaan program Gerdu Kempling. Sehingga Bappeda pun tidak pernah melakukan monev lapangan, monev hanya berupa penyerahan laporan setiap caturwulan.Monev lapangan untuk pelaksanaan program Gerdu Kempling 2013 yang lalu baru dilaksanakan pada tahun 2015 .

\section{b. Efektivitas dan efisiensi dari metode pemberdayaan yang digunakan dalam program Gerdu Kempling di kelurahan Palebon}

Efisiensi dari cara pemberdayaan program Gerdu Kempling di kelurahan Palebon berjalan baik. Tidak terjadi kekurangan dana dan pelaksanaan kegiatan pemberdayaan selesai tepat pada waktunya sesuai yang telah ditentukan oleh pemerintah kota Semarang.Namun, secara efektivitas, cara pemberdayaan program Gerdu Kempling di kelurahan Palebon tidaklah efektif. Tujuan dari pemberdayaan program Gerdu Kempling adalah menurunkan angka kemiskinan $2 \%$ setiap tahun, begitu juga lah yang seharusnya dicapai di kelurahan Palebon. Tetapi, apabila melihat jenis kegiatan dan waktu singkat yang diberikan pemerintah kota Semarang, maka kegiatan pemberdayaan di kelurahan ini sebagian besar tidak mencapai tujuannya.

Hasil pengamatan di lapangan pun menunjukkan bahwa hanya beberapa kegiatan pemberdayaan yang menunjukkan hasil dan yang lainnya tidak berpengaruh apa pun pada masyarakat.Kegiatan yang menunjukkan hasil ini adalah Pendirian Rumah Pintar serta 
terbentuknya Kampung Seni di Kelurahan Palebon dengan adanya pelatihan pembuatan payet dengan berbagai motif, pelatihan pembuatan bunga dari kain perca serta pelatihan pembuatan lukisan dari wayang kulit. Kedua kegiatan ini memang berpengaruh baik kepada masyarakat, tetapi tidak sampai pada tahap mengeluarkan mereka dari kemiskinan.
3. Output, yang diamati dari gejala:

Kegiatan-kegiatan program Gerdu kempling di kelurahan Palebon menunjukkan hasil yang berbeda-beda. Berikut adalah hasil dari tiap kegiatan program Gerdu kempling di Kelurahan Palebon:

Tabel 4

Output Program Gerdu Kempling di Kelurahan Palebon

\begin{tabular}{|c|c|c|}
\hline No. & Jenis Kegiatan & Hasil Kegiatan \\
\hline 1. & $\begin{array}{l}\text { Pendirian Rumah } \\
\text { Pintar }\end{array}$ & $\begin{array}{l}\text { Adanya tempat yang digunakan anak-anak } \\
\text { Kelurahan Palebon untuk belajar dengan } \\
\text { fasilitas } 2000 \text { buku bacaan yang disediakan, } \\
\text { komputer dan layanan internet gratis }\end{array}$ \\
\hline 2. & Pengobatan gratis & $\begin{array}{l}\text { Masyarakat bisa mendapatkan layanan check- } \\
\text { up kesehatan gratis }\end{array}$ \\
\hline 3. & Bantuan Penghijauan & $\begin{array}{l}\text { Bertambahnya jumlah pohon di kelurahan } \\
\text { Palebon }\end{array}$ \\
\hline 5. & Mind Set Training & Bertambahnya pengetahuan masyarakat. \\
\hline 6. & Pelatihan Tata Boga & $\begin{array}{l}\text { Bertambahnya skill masyarakat dalam } \\
\text { pembuatan serabi }\end{array}$ \\
\hline 7. & $\begin{array}{l}\text { Penyuluhan Kesehatan } \\
\text { Masyarakat }\end{array}$ & Bertambahnya pengetahuan masyarakat. \\
\hline 8. & $\begin{array}{l}\text { Pelatihan pembuatan } \\
\text { kerajinan payet, bunga } \\
\text { dari kain perca dan } \\
\text { lukisan wayang kulit. }\end{array}$ & $\begin{array}{l}\text { Menghasilkan produk-produk kerajinan seperti } \\
\text { hiasan payet kaligrafi, bunga, lukisan yang } \\
\text { memiliki nilai jual. }\end{array}$ \\
\hline
\end{tabular}

Output dari masing-masing kegiatan tersebut dirasakan secara berbeda-beda oleh masyarakat miskin kelurahan Palebon karena tidak semua masyarakat yang dilibatkan dalam program Gerdu Kempling mengikuti semua kegiatan secara merata. Ada warga yang hanya terlibat dalam satu kegiatan, namun juga ada warga yang terlibat lebih dari satu kegiatan. Jumlah KK miskin yang ada di kelurahan Palebon menurut Staf Kesra kelurahan Palebon Ibu Sainah adalah 488 KK miskin. Tetapi tidak semua KK miskin tersebut dilibatkan dalam kegiatan-kegiatan program Gerdu Kempling. Beliau mengirangira kurang lebih ada seratus lebih sedikit KK. Angka tidak pasti ini dikarenakan kelurahan Palebon tidak memiliki data by name by address masyarakat yang mengkuti program Gerdu Kempling. Pernyataan dari Staf Kesra Kelurahan Palebon menunjukkan 
bahwa kurang lebih warga yang dilibatkan dalam program Gerdu Kempling adalah 30\% saja. Sisanya tidak dilibatkan dan tidak mendapatkan pengaruh apapun dari program Gerdu Kempling. Sebagian besar masyarakat kelurahan Palebon yang terlibat dalam program Gerdu Kempling berasal dari RW 4 karena kantung kemiskinan kelurahan Palebon sebagian besar ada di wilayah itu. Jenis-jenis kegiatan program Gerdu Kempling di Kelurahan Palebon tidak bersifat berkelanjutan dan tidak bersifat merubah kehidupan masyarakat menjadi lebih baik secara signifikan. Namun, ada 33\% masyarakat yang menyatakan mendapatkan hasil yang menguntungkan. Sebagian besar yang menjawab setuju tersebut adalah ibu-ibu yang mengikuti kegiatan pelatihan pembuatan serabi dan keterampilan membuat kerajinan payet, bunga dari kain perca serta lukisan wayang kulit karena seperti yang telah dijelaskan di atas bahwa kegiatan ini masih berjalan sampai dengan sekarang dan ibu-ibu tersebut mendapatkan tambahan pemasukan dari hasil penjualan kerajinan tersebut.Hasil berdasarkan data kuantitatif sekunder, menunjukkan, 1).Masyarakat dapat menghasilkan produk atau kebiasaan/pekerjaan baru yang menguntungkan dari kegiatan pemberdayaan program Gerdu Kempling. Sebagian besar yang menjawab setuju tersebut adalah ibu-ibu yang mengikuti kegiatan pelatihan pembuatan serabi dan keterampilan membuat kerajinan payet, bunga dari kain perca serta lukisan wayang kulit karena seperti yang telah dijelaskan di atas bahwa kegiatan ini masih berjalan sampai dengan sekarang dan ibu-ibu tersebut mendapatkan tambahan pemasukan dari hasil penjualan kerajinan tersebut; 2).Masyarakat dapat mandiri melakukan kegiatan tanpa intervensi/campur tangan pemerintah lagi setelah program Gerdu Kempling selesai dilaksanakan di kelurahan Palebon; 3).Produk yang dihasilkan melalui program Gerdu Kempling dapat dijual dan meningkatkan pandapatan keluarga. Masyarakat sebagian besar memilih tidak berpendapat atau netral. Hal ini dikarenakan pertama, sebagian besar kegiatan-kegiatan program Gerdu Kempling tidak menghasilkan suatu produk.

Berdasarkan penelitian ini, maka dapat diketahui bahwa dampak yang paling besar dirasakan masyarakat miskin di Kelurahan Palebon adalah pertama, kegiatan pemberdayaan di bidang lingkungan dan kesehatan masyarakat yaitu bantuan penghijauan, pengobatan gratis. Kedua, kegiatan pemberdayaan di bidang infrastruktur yaitu pendirian rumah pintar.Ketiga, kegiatan pemberdayaan di bidang ekonomi yaitu pelatihan kerajinan payet, bunga dari kain perca serta lukisan dari wayang kulit.Kegiatan-kegiatan tersebut dapat memberikan dampak kepada masyarakat dikarenakan hasil dari kegiatan tersebut sampai sekarang masih dapat dirasakan masyarakat.

\section{PENUTUP}

1. Kesimpulan

a) Ketepatan Input Program Gerdu Kempling di Kelurahan Palebon

Input pada tiap kegiatan pemberdayaan program Gerdu Kempling sudah tepat, dana yang diberikan tidak mengalami kekurangan untuk membeli bahan-bahan yang dibutuhkan guna pelaksanaan kegiatan dan sumber daya manusia pada masing-masing kegiatan pun juga tidak mengalami kekurangan dan hambatan dikarenakan orang-orang yang ditunjuk untuk melaksanakan kegiatan adalah orang-orang yang tepat dan ahli terhadap bidang tersebut.

b) Proses Program Gerdu Kempling di Kelurahan Palebon

Pada tahap Proses terdapat masalah dalam pentransformasian kebijakan ke dalam bentuk pelayanan langsung ke masyarakat yang berpengaruh pada hasil kebijakan dan dampak yang dirasakan masyarakat yaitu waktu pemberdayaan yang singkat yakni hanya 1 tahun, jenis-jenis kegiatan yang tidak sesuai dengan kebutuhan masyarakat dan 
tidak berkelanjutan, dan monev hanya bersifat administrasi serta tidak adanya ukuran keberhasilan program.

c) Dampak program Gerdu Kempling di Kelurahan Palebon

Dampak yang paling besar dirasakan masyarakat miskin di kelurahan Palebon adalah pertama, kegiatan pemberdayaan di bidang lingkungan dan kesehatan masyarakat yaitu bantuan penghijauan, bantuan pengobatan gratis .Kedua, kegiatan pemberdayaan di bidang infrastruktur yaitu pendirian rumah pintar, revitalisasi jalan raya.Adapun yang terakhir, kegiatan pemberdayaan di bidang ekonomi yaitu pelatihan pembuatan payet, bunga dari kain perca, pelatihan pembuatan lukisan dari wayang serta pelatihan pengolahan serabi.Kegiatan-kegiatan tersebut dapat memberikan dampak kepada masyarakat dikarenakan hasil dari kegiatan tersebut sampai sekarang masih dapat dirasakan masyarakat. Melalui adanya bantuan pelatihan ini dapat membantu pertumbuhan ekonomi dan lapangan usaha di kelurahan Palebon yakni dengan bertambahnya 19 buah toko dan warung kecil. Yang semula jumlahnya hanya 188 buah meningkat jumlahnya menjadi 207 buah dalam kurun waktu 1 tahun pasca bantuan program Gerdu Kempling.

Secara keseluruhan dapat disimpulkan bahwa kegiatan program Gerdu Kempling berjalan dengan baik dan lancar walaupun terdapat permasalahan dalam pentransformasian program ke dalam bentuk pelayanan langsung kepada masyarakat sehingga pelaksanaan program Gerdu Kempling di Kelurahan Palebon belum dapat memandirikan masyarakat.

2. Saran

a) Waktu pelaksanaan kegiatan pemberdayaan harus ditambah, baik itu dari sisi perubahan kebijakan Program Gerdu Kempling dari Bappeda Kota Semarang atau pun inisiatif CSR.

b) Jenis kegiatan harus sesuai dengan kebutuhan dan keadaan masyarakat yaitu dengan cara masyarakat sasaran kebijakan dilibatkan sejak awal dalam perumusan kegiatan dan Bappeda pun harus terlibat untuk menjamin bahwa kegiatan yang dibuat benar-benar sesuai dengan kebutuhan masyarakat dan menjamin kegiatan tersebut merupakan kegiatan yang berkelanjutan serta bisa membawa masyarakat pada kemandirian. Selain itu, Bappeda harus memiliki syarat dan standar untuk kegiatan pemberdayaan dalam program Gerdu Kempling.

c) Pihak kelurahan harus membuat daftar by name by address masyarakat target sasaran pengentasan kemiskinan program Gerdu Kempling.

d) Indikator atau ukuran keberhasilan program harus segera disusun sebagai bahan untuk evaluasi lapangan dan timbal balik terhadap kegiatan pemberdayaan yang telah dilakukan.

e) Monitoring dan Evaluasi lapangan harus dilakukan secara rutin setiap catur wulan sehingga apabila terdapat masalah dalam pelaksanaan kegiatan pemberdayaan dapat segera diperbaiki.

\section{DAFTAR PUSTAKA}

Ambar Teguh Sulistyani, 2004, Kemitraandan Model-Model Pemberdayaan. Yogyakarta : Graha Ilmu.

Badaruddin, 2008, Implementasi Tanggung Jawab Sosial Perusahaan Terhadap Masyarakat Melalui Pemanfaatan Potensi Modal Sosial:Alternatif Pemberdayaan Masyarakat Miskin di Indonesia, USU, Medan.

Badjuri, Abdulkahar dan Yuwono, Teguh, 2002, Kebijakan Publik: Konsep dan Strategi. Semarang: Universitas Diponegoro 
Caiden, Gerald E.1991.Administrative Reforms Comes Of Ages.New York: Walter TheGruyter

Chotib, 2008, Model Pemberdayaan Lokal yang Berkelanjutan Melalui Program CSR, Warta Demografi FE UI, Jakarta.

Davis, Keith dan John W. Newstrom. 1985. Perilaku dalam Organisasi, Penerbit Erlangga

Davison, R. M., Martinsons, M. G., Kock N., (2004), Journal : Information Systems Journal : Principles of Canonical Action Research 14, 65-86

Miles,M.B, Huberman,A.M, danSaldana,J. 2014.Qualitative Data Analysis, A Methods Sourcebook Edition 3. USA : Sage Publications.

Soetomo. 2006. Strategi-Strategi Pembangunan Masyarakat. Yogyakarta: PustakaPelajar

Sugiyono. 2007. Metode Penelitian Kuantitatif Kualitatif dan $R \quad \& \quad D$. Bandung: Alfabeta

Suharto, Edi. 2005. Membangun Masyarakat Memberdayakan Rakyat: Kajian
Strategis Pembangunan

Kesejahteraan Sosial \& Pekerjaan Sosial, Bandung :Refika Aditama

Sukardi. 2008. Metodologi Penelitian Pendidikan, Kompetensi dan Praktiknya. Jakarta : PT. Bumi Aksara.

Sulaksana,U., (2004), Managemen Perubahan, Cetakan I, Pustaka Pelajar Offset, Yogyakarta.

Steers, Richard M. 1980. Efektivitas organisasi :kaidah tingkah laku. Jakarta: Erlangga.

Thoha, Miftah. 2001. Dimensi-dimensi Prima Ilmu Administrasi Negara. Jakarta: PT, Raja Grafindo Persada

Wibawa, Samodra.2009. Administrasi Negara Isu-isu Kontemporer.Yogyakarta: Grahallmu

Wibawa,Samodra, Yuyun, Purbokusumo, dan Agus P, 1994. Evaluasi Kebijakan Publik. Jakarta: PT. Raja Grafindo

Wilson, Terry, 1996, The Empowerment Mannual, London: Grower Publishing Company. 